\title{
The Effectiveness of Car Advertising Media: Perceptions of Generation-Y Consumers
}

\author{
Thérèse Roux \\ Tshwane University of Technology \\ Email: rouxat@tut.ac.za
}

\section{Doi:10.5901/mjss.2014.v5n20p1877}

\begin{abstract}
Car advertising is new and unique form of Out-of-home advertising and presents a unique opportunity for advertisers to reach a variety of targeted audience profiles. This study explores the effectiveness of car advertising from the perspective of Generation $Y$ consumers. The target audience comprises students between the ages of 18 and 30 years at two of the largest residential universities in South Africa. Convenience sampling was used and a total of 400 questionnaires were completed. The results indicated that there is a positive correlation between recall and attention paid to car advertising; between attitudes towards advertising on cars and the recall thereof; and consumer's general attitude towards advertising and their attitude towards car advertising. It also revealed that car advertising is far from being unnoticed by Generation Y, who, in fact, accepted it better than was anticipated. The findings also implied that the medium is more effective when respondents' have a more positive attitude towards advertising in general.
\end{abstract}

Keywords: alternative media, out-of-home advertising media; car advertising; transit advertising media; out-of-home advertising media, Generation-Y.

\section{Introduction}

Moving away from just aiming to reach as many potential customers as possible at as low a cost as possible cost, towards a more audience-centred view has led to the increasing realisation that besides traditional advertising, there are a variety of alternative media to communicate and build relationships with consumers. Brand-customer touch points are surely no longer restricted to mass media or traditional advertising, but include each and every potential experience a customer or prospect has to interact with, or see, or hear about the company and/or its brands (Belch \& Belch, 2012, p. 26).

These marketing-created touch points comprise an ever increasing variety, ranging from traditional mass advertising to direct marketing, sales promotions, events and sponsorships, personal selling and more recently product placement, branded entertainment, viral-marketing, guerrilla-marketing, event marketing, mobile marketing, in-store marketing, point-of-purchase displays, social media, cell phone media, internet advertising and transit advertising media (Belch \& Belch, 2012, p. 26; Blakemen, 2007, p. 260, Clow \& Baack, 2010, p. 313; Jurca, 2010, p. 323). The primary focus of this study is on just one of these types of contact points: car advertising media. Car advertising is a part of the transit advertising media platform within the larger out-of-home $(\mathrm{OOH})$ advertising media class.

Despite the wide variety of contemporary formats and types, $\mathrm{OOH}$ advertising has not received the attention it deserves in the literature. Very limited studies have been published on this topic. Past studies have focused mostly on the effectiveness of traditional outdoor advertising or free standing billboards (Donthu \& Bhargava, 1999; Donthu, Cherian, \& Bhargava, 1993, Nagel \& Louw, 2004; Osborne \& Coleman, 2008; Pauwels, 2005, Taylor \& Franke, 2003; Taylor, Franke \& Bang, 2006, Wilson \& Till, 2011; Woodside, 1990) and only recently explored transit advertising media such as taxi advertising (Veloutsou \& O'Donnell, 2005) airport advertising (Wilson \& Till, 2008) and advertising at subway train stations (Chan \& Fung, 2103). None of these studies have investigated the effectiveness of car advertising media in an emerging market such as South Africa.

It will therefore be valuable to explore the effectiveness of car adverting. The apparent gap in the literature on car advertising means that further research is needed to decipher exactly how this new unique form of $\mathrm{OOH}$ advertising differs from general transit advertising, as well as its relative effectiveness as indicated through constructs such as unaided recall, attitudes, attention and perceptions.

The focus of this paper is specifically on car advertising media, from the perspective of Generation-Y consumers. Car advertising, as a type of moving exterior transit advertising media, refers to when a company places its product or service information, contact details and/or company name on the car itself. 
The perceptions of Generation-Y consumers is explored, since a number of the leading transit advertising media companies in South Africa offer student car advertising by branding student vehicles with suitable brands to target this cohort (OHMSA, 2012). Furthermore no previous studies could be found on this unique medium, as studies on Generation-Y consumers investigated other types of media such as print media, broadcast media, cellular advertising, internet and social media (Bolton, Parasuraman, Hoefnagels, Migchels, Kabadayi, Gruber, Loureiro, \& Solnet, 2013; Berndt, 2007; Jordaan \& Ehlers, 2009; Jordaan, Ehlers, \& Grove, 2011).

\section{Literature Review}

In this section, Generation Y consumers are reviewed by highlighting their characteristics and their usage and perception of media vehicles. Then car advertising media are contextualised within $\mathrm{OOH}$ advertising and transit advertising, followed by a discussion on car advertising.

\subsection{Generation Y or Millennials}

Brosdahl and Carpenter's (2011) used the Generational Cohort Theory (GCT) as a framework to examine the shopping orientations of US men. They distinguished between four different generational cohorts based on their birth dates: the Silent Generation (1925-45), the Baby Boomers (1946-60), Generation X (1961-80) and Generation Y (born after 1980). Generation $Y$ often referred to as Millennials (or even the Facebook-, Hip-hop- or Kwaito generation) are the offspring of the Baby Boomers or Generation X. The term Generation Y first appeared in an Ad Age editorial in 1993 to describe teenagers of the day, which they defined as separate from Generation $X$. There is not (as yet) widespread agreement on the start and end points for Generation Y. Berndt (2007), included people born between 1977 and 1994 in her study on the media habits of Generation Y. In 2011, Jordaan, Ehlers, and Grove (2011) included those aged between 18 and 30 years in their study on Generation Y's perceptions of the credibility of traditional and new media channels. Most studies consider Generation $Y$ as a single homogeneous cohort; some of these studies compare and contrast Generation $Y$ with other cohorts such as Generation Y and the Baby Boomers (Brosdahl \& Carpenter, 2011; Christofides, Muise, \& Desmarais, 2012).

However, there is likely to be significant heterogeneity within Generation $Y$ in terms of media usage and attitudes. Researchers therefore typically study Generation $Y$ by focusing on distinct subgroups - high school learners, university students, university graduates looking for a job, and employees early in their careers - who differ in age and lifecycle stage and, therefore, may differ in their media usage and attitudes (Bolton, Parasuraman, Hoefnagels, Migchels, Kabadayi, Gruber, Loureiro, \& Solnet, 2013, p.25). For the purpose of this study university students aged between 18 and 30 will be surveyed.

The literature has highlighted similarities between the individuals that make up Generation $Y$, showing that generally they are highly techno-literate due to early and frequently exposure to technology and social media; well educated, expecting rapid career advancement and demanding more work/life balance than previous generations; particularly self-confident about their intelligence, performance and attractiveness; materialistic and receptive to customised products and personalised services (Bolton et al. 2013; Twenge, 2010; Twenge \& Campbell, 2008).

Within South Africa, some researchers have delved into Generation Y consumers' perception and exposure to media vehicles. Berndt (2007) determined that only a few respondents exposed themselves to print media, while the majority of the respondents open themselves up for broadcast media. Jordaan and Ehlers (2009) reported that they use new media (cell phone media and internet advertising) more frequently than traditional media (print and broadcast advertising). Conversely, they regard the credibility of traditional media higher compared to those of new media such as cellular advertising and internet media (Jordaan, Ehlers, \& Grove, 2011). However no research has been published on how this generation feel about car advertising, a meduim often used to target them specifically (OHMSA, 2012).

\section{$2.2 \mathrm{OOH}$ advertising media}

$\mathrm{OOH}$ advertising media comprise of four major media platforms: (1) outdoor advertising; (2) transit media advertising; (3) street- and retail-furniture advertising; and more recently, (4) digital and ambient $\mathrm{OOH}$ media channels (Roux, Van der Waldt, and Ehlers, 2013, p. 383). Globally, outdoor advertising media expenditure is predicted to reach US\$32,4 billion (R339, 573 billion) in 2016 (Magna Global, 2011:24). Nielson Media Research (2012) reports that more than R1,6 billion (152 297600 US \$) was spent on OOH advertising media in South Africa during 2012, with R868 977000 (82 714445 US\$) of spending on outdoor advertising or billboards representing the largest share of approximately $54 \%$. The second 
largest category was transit media with R266 276000 (25 345 747US\$) or 16,68\%, followed by street and retail furniture advertising such as signs, benches and kiosks at R264 216000 (25 227079 US\$) or 16,54\%) and alternative $\mathrm{OOH}$ advertising media types (advertisements painted on walls - 3,13\%; electronic signage - 1,54\%; premise signage - 0,02\%; stadia promotions $-0,04 \%)$. Recently this media landscape has expanded even more, to include a variety of new transit advertising media options such as at the Gautrain station, the bus-rapid transit system and digital advertising in minibus taxis and at ranks (Roux et al., 2013, p. 391).

The $\mathrm{OOH}$ advertising media sector will continue to grow and diversify over the next decades, not only because of its cost-effectiveness, but also because it seems to be the only available realm from which to reach progressively elusive consumers, and the ideal anchor of integrated marketing communication (IMC) campaigns (Lopez-Pumarejo and Myles, 2009, p. 38).

\subsection{Transit advertising media}

Transit advertising media consist of moving transit media and static or stationary advertising (Roux et al., 2013, p. 390). Moving transit media include displays affixed to the outside or inside of moving vehicles, trains, buses, taxis or cars. Static or stationary advertising is positioned in the common areas of train stations, taxi ranks, terminals and airports. Belch and Belch (2012) distinguish between two types of moving transit advertising media: Interior and exterior (p. 452). Interior transit advertising is aimed at the commuters riding inside the buses, trains, and taxis. Exterior transit advertising, on the side, front or rear of vehicles, is aimed at pedestrians in the streets and people in nearby cars. Interior transit advertising exposes a captive audience to the message for a longer period of time, while inside a bus, train or taxi. Since the time of exposure to the message is longer than that, for example, in outdoor advertising, it may be used for a longer or more complicated message to the target market (Moriarty, Mitchell, \& Wells, 2012, p. 367).

Transit advertising is effective for advertisers who wish to target commuter that live and work in major metropolitan areas. It is considered to be an effective means of delivering wide coverage to a large number of people, as well as detailed, repetitive messaging, by placing it on specific routes, or at specific stations (Moriarty et al., 2012, p. 367). Transit advertising media can also be used creatively; and have the potential to bring the advertiser's message straight to a wide variety of commuters, where outdoor advertising may be restricted or not as effective (Du Plooy, 2012, p. 286).

Transit advertising is not without limitations. It often has to compete for attention with potential distracting stimuli in the transit environment, and can result in wasted media coverage to people who are not part of the target market (Sissors \& Baron, 2010, p. 266). It can also be difficult for advertisers to use transit media to engage with daily commuters, because they can be tired, bored or too absorbed in their thoughts to even notice a message (O'Guinn, Allen, and Semenik, 2000, p. 588).

A way to overcome some of the limitations is to employ transit advertising as a secondary or support advertising medium, since it works best in conjunction with other mediums, such as television and radio (Veloutsou and O'Donnell, 2005, p. 218). Transit advertising can also be combined with radio advertising (Gray, 2008); or mobile phones to generate feedback that allows advertisers to examine those who are viewing and interacting with the messages (Wayne, 2010).

\subsection{Advertising on cars}

Car advertising differs from other types of $\mathrm{OOH}$ advertising media. Outdoor advertising media or billboards are static and consist of advertisements on larger format free-standing displays, next to the road and on buildings, walls and other constructions, typically used to reach the mass market or large number of travellers in vehicular traffic (OHMSA, 2012). Unlike other mass transit advertising media vehicles such as busses and trains that are limited to specific routes, a car generally has no boundaries and can virtually travel anywhere. In South Africa mass transit advertising media are mainly used to reach a broad commuter market, while car advertising offers opportunities for advertisers to reach very specific consumer segments. This is achieved by matching the car owners' lifestyles with the target market of the product or service being advertised (Du Plooy, 2012, p. 265).

There are a wide variety of different measures to assess the effectiveness of advertising and media (Belch and Belch, 2012, p. 157; Moriarty et al., 2012, p. 581; O'Guinn et al., 2012, p. 266; Shimp, 2010, p. 288). Furhermore the measuring of advertising effectiveness can be complex, because of inter-related factors that contribute to the ultimate success. Hence, advertising effectiveness tends to be evaluated through other measurement constructs, such as unaided recall, attitudes, attention and change in perceptions or attitudes (Belch and Belch, 2012, p. 157; Moriarty et al., 2012, p. 581; O'Guinn et al., 2012, p. 225; Shimp, 2010, p. 288).

Contemporary consumers live in an increasingly cluttered media environment. Therefore grabbing their attention is 
often crucial for effective delivery of a marketing message. By definition, attention reflects the level of focus given to an advertisement, specifically, whether advertisement processing is a primary or secondary task. As attention increases, more working memory or short-term memory capacity is allocated to the stimulus or advertisement (Smith \& Yang, 2004, p. 40).

Often, the more creative the advertisement or novel the medium, the more attention will be paid to it. Since advertising on cars is a relatively new and creative form of transit advertising, it is probable that it will attract additional attention as it imparts information in an entertaining and interesting way (West, Kover, and Caruana, 2008, p. 35). Baack, Wilson, and Till (2008) also suggests that creative advertising on alternative media leads to greater processing of information at a deeper level, because it can attract more attention. Since it attracts more attention it is likely that it will also lead to greater recall of the advertisement (p. 87). Donthu, Cherian and Bhargava (1993) proved a correlation between the attention given to an outdoor advertisement and the ability to recall that particular advertisement.

Measures of aided and unaided recall are used to evaluate the effectiveness of advertising or components of the advertising message, such as size, colour, headings, visuals or slogans to influences brand awareness and brandrelated concepts. The theory is that memorable advertisements, placed in a medium at the right time and place, would probably be most effective (O'Guinn et al., 2012, p. 257). Recall is one of the widely used measures of effectiveness. It has been used to measure the effectiveness of several $\mathrm{OOH}$ advertising media types (Bhargava et al., 1994; Berneman \& Kasparian, 2003; Donthu et al., 1993; Turley \& Shannon, 2000), including transit advertising media (Baack et al., 2008; Chan \& Fung, 2103; Predergast \& Hang, 1999; Wilson \& Till, 2008). This study focused on the measurement of unaided recall of advertising on cars. Unaided recall refers to where a person is asked to remember information without assistance, in other words, in a spontaneous manner.

Related to recall is the level of attention paid to the advertising medium. Attention is often subconscious; therefore the information or message is often left unprocessed in the mind of the consumer. A higher the level of attention paid to an advertising medium can increase the level of conscious noting and thus lead to higher level of awareness (Ehrenberg et al., 2002, p. 8). It is only when more attention is given to a particular advertisement that deeper processing will occur (Baack et al., 2008, p. 86), and thus the advertisement will be more likely to be recalled. Therefore, it can be said that the more attention given to an advertising medium, the better the chances that recall will occur.

This study explores the effect that the degree of attention given to cars advertising has on the ability to recall the advertising. The following hypothesis is stated:

- $\mathrm{H}_{01}$ : There is no correlation between the unaided recall of advertisements on cars and the amount of attention given to the advertisements.

- $\mathrm{H}_{1}$ : There is a correlation between the unaided recall of advertisements on cars and the amount of attention given to the advertisements.

There is more to the effectiveness of an advertising medium than the respondent's ability to recall the advertisement. The target audience's feelings and perceptions also need to be taken into consideration when determining the effectiveness of advertising media (Veloutsou \& O'Donnell, 2005, p. 223). Dahlén and Edenius (2007, p. 42) found that new and creative advertising formats such as placing an advertising message in a non-traditional advertising medium result in more favourably attitude towards the message conveyed. Furhermore studies in developed countries (Eun \& Kim, 2009; Veloutsou \& O'Donnell, 2005), as well emerging countries (Du Plooy \& Du Plessis, 2011; Nagel \& Louw, 2004) have tested and confirmed the effectiveness of $\mathrm{OOH}$ advertising on this attitudinal level. Consumer's attitudes can influence how consumers respond to an advertisement and remember it (Prendergast \& Hang, 1999, p. 36). Furhermore, Osborne and Coleman (2008) and Donthu et al. (1993) found that consumers with a more favourable attitude to advertising were likely to recall more outdoor advertisements. Thus consumers who have a more positive attitude towards advertising in general should recall more car advertisements than those with a negative attitude. Therefore, the concepts of recall and attitudes are related, and both can be used to measure the effectiveness of an advertisement.

The second hypothesis for this paper is suggested:

- Ho2: There is no correlation between attitudes towards car advertising and unaided recall of the advertising.

- $\mathrm{H}_{2}$ : There is a correlation between attitudes towards car advertising and unaided recall of the advertising.

Consumers' perceptions of and attitudes towards advertising are also key indicators of advertising effectiveness. There has lately been an increase in measuring consumers' attitudes to advertising and the impact on the brand, as a result of the trend of more advertising directed at emotional and attitudinal responses, rather than just conveying factual information about product features (Shimp, 2010, p. 297). This is in line with Zarantonello, Jedidi and Schmitt (2013) who found that advertising which evokes sensations, feelings, and imaginations drive persuasion (p.35). Thus, people's attitudes towards advertising in general can possibly influence their acceptability of new forms of advertising, such as 
advertising on cars. Furthermore consumers' perceptions of advertising in general can influence how they are likely to perceive or react to other advertising media such as car advertising.

Based on this explanation the third hypothesis for this paper is suggested:

- $\mathrm{H}_{03}$ : There is no correlation between attitudes toward advertising in general and perceptions of advertising on cars.

- $\mathrm{H}_{3}$ : There is a correlation between attitudes toward advertising in general and perceptions of advertising on cars.

The rest of the paper is organised as follows. Firstly, the methodology, the key measures, and the results of the study are described. Next, the findings, limitations and implications for theory and practice are presented.

\section{Research Methodology}

\subsection{Sampling and data collection}

The study population consisted of full time students in any year, registered at two of the largest residential universities in South Africa. A quantitative strategy of inquiry in the form of survey research was used. Personal interviews in conjunction with a structured questionnaire formed part of the data collection process.

A pilot test of the questionnaire was done amongst a convenience sample of 20 respondents with similar characteristics as those consumers that were targeted in the main part of the study. The pilot study allowed for consideration of the length of the questionnaire, clarity of instructions, layout and flow of questions.

The selection of an appropriate sampling method is largely depended on the objectives of the study, the financial resources available, time limitations, as well as the nature of the problem under investigation. For these reasons a jugement sample was used for the study. University students were intercepted on the selected campuses and the fieldworkers explained the purpose of the survey and when a respondent indicated willingness to participate, the questionnaire was handed over for completion. A total of 400 questionnaires, equally distributed between both campuses, were completed and used for the data analysis.

\subsection{Instrument}

Due to the lack of published research on the effectiveness of advertising on cars, the objectives of this study were achieved through the replication and extension of research instruments used in previous studies on the effectiveness of other types of mobile transit advertising mediums, specifically cab advertising (Veloutsou \& O'Donnell, 2005) and minibus taxi advertising (Du Plooy \& Du Plessis, 2011). A 5-point Likert scale was used to measure respondent's attitudes towards advertising and car advertising as well as attention paid towards car advertising media. A high score on this scale indicated a positive opinion and vice versa, a low score on the scale indicated a negative opinion. The study adopted Cronbach's alpha to analyse the reliability of the data. The results showed that the scales had good Cronbach's alpha reliability scores (Attitudes towards advertising in general 0,81; Attitudes towards car advertising 0,74; Attention paid towards car advertising 0,72 ).

The data were analysed using the Statistical Package for the Social Sciences (SPSS Version 16.0 for Windows). The data were subjected to descriptive statistics utilizing minimum, maximum, mean, standard deviation, as well as hypotheses testing.

The main results and findings are henceforth presented.

\section{Findings and Discussion}

\subsection{Descriptive analysis}

Table 1 presents the demographic profile of the respondents included in this study. The sample was slightly dominated by male respondents (57\%) Age groups were distributed as follows 18-20 years old (42\%); 21-23 years old (26\%); 24-26 years old (15\%), 27-30 years old (17\%). Most of the respondents (58\%) indicated that they speak an African language at home, while the rest were English (22\%) or Afrikaans speaking (18\%). 
Table 1. Sample profile

\begin{tabular}{|c|c|c|c|}
\hline & & $\mathrm{N}$ & $\%$ \\
\hline \multirow[t]{2}{*}{ Gender: } & Male & 227 & 57 \\
\hline & Female & 173 & 43 \\
\hline \multirow[t]{4}{*}{ Age group: } & $18-20$ & 168 & 42 \\
\hline & $21-23$ & 104 & 26 \\
\hline & $24-26$ & 60 & 15 \\
\hline & $27-30$ & 68 & 17 \\
\hline \multirow[t]{3}{*}{ Home language: } & Africans & 232 & 58 \\
\hline & English & 88 & 22 \\
\hline & Afrikaans & 80 & 20 \\
\hline
\end{tabular}

The results of the recall of car advertising questions identified that $71.7 \%$ of respondents have seen a car advertisement in the two weeks preceding the completion of the questionnaire. Sixty percent of the respondents who saw a car advertisement were able to recall the brand name on the car. The brand names that we're recalled the most are DSTV and Red Bull, with $17.6 \%$ and $16.2 \%$ respectively of all the brand names recalled.

The mean $(M)$ of the composite score for the attitude towards advertising $(M=3.7)$ suggests respondents have relative positive attitude towards advertising in general (see table 2). Respondents indicated that advertising informs them about products $(M=4.02, S D=0.94)$, that they find advertising entertaining $(M=3.98, S D=0.96)$ and that I often try a new product because of an advertisement $(M=4.01, S D=1.22)$. Respondents however disagreed that they switch brands because of an advertisement $(M=2.79, S D=1.16)$.

When considering the attitude towards car advertising, the mean composite (total) score $(M=3,63)$ also suggest relative positive attitudes towards car advertising. Respondents' answers to the statement "The concept of car advertising is a "novel" one" ( $M=4.05, S D=0.86)$ suggests that respondents regard this type of advertising as new. The standard deviation reveal that there are a narrow spread of responses to this question. In other words, respondents tended to answer this question in more or less the same way.

The mean composite score of the attention paid to car advertising $(M=3.19)$ suggests that car advertising is neither effective nor ineffective. Respondents did disagree with the statement "I remember car advertisements more than advertisements in other media $(M=2.75, S D=1.32)$ advertisements.

Table 2. Means and standard deviations of the scales used

\begin{tabular}{lccc|}
\hline & N & Mean & Std. Dev. \\
\hline Attitudes towards advertising in general & 400 & 3,70 & 1,04 \\
Advertisements help me learn about products & 400 & 4,02 & 0,94 \\
I find ads entertaining & 400 & 3,94 & 0,96 \\
I buy mostly well-known products & 400 & 3,98 & 1,0 \\
Advertisements are a necessary part of our society & 400 & 3,84 & 0,97 \\
I think most advertisements are irritating (reversed scored) & 400 & 3,22 & 1,06 \\
I often try a new product because of an advertisement & 400 & 4,01 & 1,22 \\
I often switch brands because of an advertisement & 400 & 2,79 & 1,16 \\
\hline Attitudes towards car advertising & 400 & 3,63 & 1,13 \\
I am familiar with the brand names advertised on cars & 400 & 3,72 & 1,06 \\
I like to look at cars covered with creative advertisements & 400 & 3,95 & 1,23 \\
The concept of car advertising is a "novel" one & 400 & 4,05 & 0,86 \\
I look at cars completely covered in an advertisement more than others & 400 & 3,64 & 1,23 \\
I have spoken to other people about car advertising I have seen & 400 & 2,81 & 1,28 \\
\hline Attention paid towards car advertising by regular commuters & 400 & 3.19 & 0.92 \\
I often notice advertisements on passing cars & 400 & 3.57 & 1.08 \\
I often read advertisements on cars & 400 & 3.38 & 1.17 \\
I pay attention to the emergence of new car advertisements & 400 & 3.07 & 1.18 \\
I remember car advertisements more than advertisements in other media & 400 & 2.75 & 1.32 \\
\hline
\end{tabular}

Table 3 shows the descriptive statistics for the individual elements of advertisements recalled. It can be seen that 'Pictures/photos' were recalled the most $(N=284)$, with followed by 'colours' $(N=218)$. 'Letter types' were the least 
recalled $(N=16)$. For each brand or company name recalled, most of the respondents recalled at least two individual elements.

Table 3. Descriptive statistics for individual elements of advertisements on cars

\begin{tabular}{lccc|}
\hline Elements of advertisements & $N$ & Minimum & Maximum \\
\hline Colours & 218 & 1 & 6 \\
Symbols & 126 & 1 & 4 \\
Phone numbers & 66 & 1 & 4 \\
Pictures/photos & 284 & 1 & 4 \\
Letter types & 16 & 1 & 2 \\
Writing recalled & 82 & 1 & 5 \\
\hline
\end{tabular}

$N=$ Number of respondents

Table 4 indicates the ranking of eight major advertising media tested. It indicates that the respondents regard television advertising as the most successful in communicating a commercial message (Sum $=2620$ ). Advertising on cars is the fourth most successful in communicating a message (Sum = 1626). Finally, SMS advertising (Sum = 1084) and handouts at robots are perceived to be the least successful (Sum $=956)$.

Table 4. Ranking of advertising media

\begin{tabular}{|lcc|}
\hline & $N$ & Sum \\
\hline Television advertising & 400 & 2620 \\
Radio advertising & 400 & 2104 \\
Print advertising & 400 & 1818 \\
Car branding/advertising on cars & 400 & 1626 \\
Social media & 400 & 1432 \\
Advertising on websites & 400 & 1350 \\
SMS advertising & 400 & 1084 \\
Hand-outs at robots & 400 & 956 \\
\hline
\end{tabular}

$N=$ Number of respondents

\subsection{Hypotheses testing}

The hypotheses were tested at a 5\% level of significance (i.e., $a=0.05$ ). For Hypothesis 1,2 and 3 the Pearson's product moment correlation was used. Since the variables were measured at an interval level of measurement, the suitable parametric test is the Pearson's product moment correlation, and the non-parametric alternative is Spearman's rank order correlation (Diamantopoulos \& Schlegelmilch, 2000). However, the Kolmogorov-Smirnov test indicated that variables in all the cases didn't have a normal distribution. Therefore, the assumption of normality is violated. As a result, Spearman's rank order correlation was used to test all the hypotheses.

\subsubsection{Hypothesis 1}

Hypothesis $\mathrm{H}_{1}$ dealt with whether respondent's ability to recall an advertisement on a car is related to the level of attention they give to advertising on cars. The results indicate that there is a positive correlation between the unaided recall of advertising on cars and the attention given to car advertising by the respondents. The coefficient of determination, $r^{2}$, indicates that the two variables share a $38.1 \%$ common variance. This implies that $38.1 \%$ of the variance in the one variable is explained by the variance in the other. 
Table 5. Spearman's rank order correlations for hypothesis 1

\begin{tabular}{|l|c|}
\hline & \\
\hline Correlation Coefficient & 0.312 \\
p-value (two-tailed) & 0.000 \\
$\mathrm{~N}$ & 400 \\
Coefficient of determination $\left(\mathrm{r}^{2}\right)$ & 0.381 \\
\hline
\end{tabular}

* Correlation is significant at the 0.05 level (2-tailed).

The implications of these findings are that respondents' scores on the unaided recall scale are positively correlated with their scores on the attention towards car branding/advertising on cars scale. This correlation was significant. As a result, the hypothesis $\mathrm{H}_{1}$ was accepted.

\subsubsection{Hypothesis 2}

Hypothesis $\mathrm{H}_{2}$ dealt with whether respondents' attitudes towards car advertising are correlated with their ability to recall these advertisements. The results indicate that there is a positive, correlation between attitudes towards advertising on cars and the unaided recall of car advertising, $r_{s}=0.24, p=0.001$ (two-tailed). The coefficient of determination, $r^{2}$, indicates that the two variables share a $24.1 \%$ common variance. This implies that $38.6 \%$ of the variance in the one variable is explained by the variance in the other.

Table 6. Spearman's rank order correlations for hypothesis 2

\begin{tabular}{|l|c|}
\hline & \\
\hline Correlation Coefficient & 0.386 \\
p-value (two-tailed) & 0.000 \\
$\mathrm{~N}$ & 400 \\
Coefficient of determination $\left(\mathrm{r}^{2}\right)$ & 0.241 \\
\hline
\end{tabular}

The implications of these findings are that respondents' scores on the attitude scale are positively correlated with their scores on the unaided recall of car branding/advertising on cars scale. This correlation was also significant. As a result, the hypothesis $\mathrm{H}_{2}$ was accepted.

\subsubsection{Hypothesis 3}

Hypothesis 3 focused on whether there is a correlation between consumer's general attitude towards advertising and their attitude towards car advertising. The results shown that there is a positive correlation between the consumer's attitude towards advertising in general and their attitude towards car advertising, $r_{s}=0.446, p<0.0005$ (two tailed). The coefficient of determination, $\mathrm{r}^{2}$, indicates that $33.6 \%$ of the variance in the attitude towards advertising can be explained by the variance in the attitude towards car advertising.

Table 7. Spearman's rank order correlations for hypothesis 3

\begin{tabular}{|l|c|}
\hline & \\
\hline Correlation Coefficient & 0.334 \\
p-value (two-tailed) & 0.000 \\
$\mathrm{~N}$ & 400 \\
Coefficient of determination $\left(r^{2}\right)$ & 0.336 \\
\hline
\end{tabular}

These results show that there is a positive correlation between the two variables, but although it is significant, it is a relative weak correlation. As a result, the hypothesis $\mathrm{H}_{3}$ was also accepted. 


\section{Managerial Implications and Suggestions for Future Research}

Advertising on cars offers advertisers a novel and creative way to get their advertising messages across, however it might not be a particularly good advertising medium for smaller and more private businesses as these companies tend to display very detailed information such as phone numbers, addresses and business information.

Another implication is that since this advertising medium is often 'in motion' the advertising messages on cars should be kept simple in order to ensure effective delivery. Advertisers should avoid clutter and should rather provide limited detail related to the advertised brand. In this way, advertising on cars should be used as a supporting advertising medium and should be used in collaboration with more traditional mediums.

It is also important to note that unlike mass transit media vehicles, cars are not limited to specific routes. They do have the ability to travel specific routes in order to target specific audiences. Therefore advertising on cars can be used effectively to target very specific audiences such as university students based on the routes that they travel and the lifestyle of drivers of the cars.

The focus of this study has been on car advertising from the perspective of the Y-generation, more specifically university students. Research therefore could be extended to include other distinct subgroups within this cohort, such as high school learners and employees early in their careers, as well as other cohorts such as Generation $Y$ and the Baby Boomers. It might be sensible to extend the study to consider the impact of car advertsing on other specific audience profiles at at places of convergence such as close to office parks, shopping centres and malls and schools. Another worthwhile future research agenda would be to investigate the effectiveness of car advertising to obtain different marketing communication objectives, such as the introduction of new brand versus reiteration of established brands; or the integration of car advertising with other media in an integrated marketing communication campaign.

Future studies on this topic could be to explore exactly which individual elements make car advertising on cars effective. This would provide advertisers and practitioners with valuable information as to what works and what does not. Another recommendation would be to determine whether the brand of the car used for advertising influences the effectiveness of the message to be conveyed.

\section{Concluding Remarks}

This study explored the effectiveness of car advertising, as a specific type of transit advertising media. Advertising effectiveness is a complex construct to measure; it therefore tends to be measured through other measurement concepts, such as unaided recall, attitudes, attention and perceptions. There has been little very research conducted on the effectiveness of advertising on cars. Current research has mainly focused on outdoor advertising and some other forms of public transit advertising mediums. This study therefore served to bridge this apparent gap in the existing literature.

With respect to unaided recall of individual elements the results indicated that respondents could recall pictures and colours the most. This implies that these elements attract the most attention and are therefore most recalled on an unaided basis. From the results it can be deduced that advertisements on cars are most effective in terms of recall and attention if the focus is on specific colours and eye-catching designs. This is in line with previous studies, which indicated that creative eye catching advertisements facilitate recall (Baack et al., 2008; Chan \& Fung, 2103). Thus, the creative use of individual elements in advertisements and avoidance of clutter, in the form of unnecessary information can be used to increase the attention grabbing capability of advertising on cars.

With regard to the Generation Y's attitudes towards advertising on cars and the ability to recall the advertisement, the results showed that there was a significant correlation between the two constructs. The results indicated that those respondents' who had favourable attitudes towards advertising on cars were more able to recall several advertisements on cars. According to Veloutsou and O'Donnell (2005) it is not common for people to express positive attitudes towards any particular advertising medium. Therefore in this study, it is surprising that respondents' showed rather favourable attitudes towards advertising on cars. This might be due to Generation-Y considering this to be a relatively new and novel advertising medium. Previous studies state that positive attitudes towards advertising in general lead to greater recall of advertisements than those with a negative attitude (Osborne \& Coleman, 2008; Donthu et al., 1993, Prendergast \& Hang, 1999). The results of this study also indicated a definite relationship between attitudes towards car advertising and the ability to recall advertising on cars.

The results showed that respondents' perceptions towards advertising in general were positively correlated with their perceptions of advertising on cars. This result was however expected as according to Veloutsou and O'Donnell (2005) perceptions of advertising in general can have an influence the acceptability of new forms of advertising, such as advertising on cars. Since perceptions towards advertising on cars were relatively positive, this is a good indicator of the 
effectiveness of the medium because perceptions can be one of the major barriers to effective advertising. As perceptions are one of the most reliable measures of effectiveness (Veloutsou \& O'Donnell, 2005), this study showed that advertising on cars is effective as a transit advertising medium from the $Y$ generations' perspective.

Du Plooy, 2012: 286 (top p. 5) other instances Du Plooy

Veloutsou, C. \& O'Donnell, C. 2005. Exploring the effectiveness of taxis as an advertising medium. International Journal of Advertising, 24(2):217--239. (Remove extra - )

\section{References}

Baack, D.W., Wilson, R.T., \& Till, B.D. (2008). Creativity and memory effects: Recall, recognition and an exploration of non-traditional media. Journal of Advertising, 37(4): 85-94.

Belch, G.E., \& Belch, M.A. (2012). Advertising and promotion an integrated marketing communications perspective. 9th th ed. Boston, MA: McGraw Hill Higher Education.

Berneman, C., \& Kasparian, M.J. (2003). Promotion of cultural events through urban postering - an exploratory study of its effectiveness. International Journal of Arts Management, 6(1):40-49.

Berndt, A. (2007). Media habits among Generation Y consumers. Proceedings of the 19th Annual conference of the Southern Institute of Management Scientists, Johannesburg, South Africa, 19-12 September, 13-16.

Bhargava, M., Donthu, N., \& Caron, R. (1994). Improving the effectiveness of outdoor advertising: Lessons from a study of 282 campaigns. Journal of Advertising Research, 34(2), 46-55. Mar-Apr

Blakeman, B. (2007). Integrated marketing communication: creative strategy from idea to implementation. Plymouth: Rowman \& Littlefield.

Bolton, R.N., Parasuraman, A., Hoefnagels, A., Migchels, N., Kabadayi, S., Loureiro, Y.K., Gruber, T., Solnet, D. (2013) Understanding Generation $Y$ and their use of social media: a review and research agenda. Journal of Service Management, 24(3:245-267.

Brosdahl, D. J., \& Carpenter, J. M. (2011). Shopping orientations of US males: A generational cohort comparison. Journal of Retailing and Consumer Services, 18: 548-554.

Christofides, E., Muise, A., \& Desmarais, S. (2012). Hey mom, what's on your Facebook? Comparing Facebook disclosure and privacy in adolescents and adults. Social Psychology and Personality Science, 3(1): 48-54.

Clow, C.E., \& Baack, D. (2010). Integrated advertising, promotion, and marketing communitarian. $4^{\text {th }}$ ed. Upper Saddle River, New Jersey: Prentice Hall.

Diamantopoulos, A., \& Schlegelmilch, B.B. (2000). Taking the fear out of data analysis: a step-by-step approach. London: Business Press.

Chan, K., \& Fung, M. (2013). Effectiveness of subway advertising in Hong Mong. Journalism and Mass Communication, (3)12:757-767.

Donthu, N., \& Bhargava. M. (1999). Sales response to outdoor advertising, Journal of Advertising Research, 39(4): 7-18.

Donthu, N., Cherian, J., \& Bhargava, M. (1993). Factors influencing recall of outdoor advertising, Journal of Advertising Research, 33(3): 64-72.

Du Plooy, A.T., \& Du Plessis, G. (2011). Exploring the effectiveness of minibus taxis as an advertising medium in an emerging market. Proceedings of the Thirteenth Annual International Conference of the Global business \& Technology Association, Istanbul, 12-16 July, 757-764.

Du Plooy, A.T. (2012). A framework for the planning and integration of out-of-home advertising media in South Africa. Thesis: University of Pretoria. http://upetd.up.ac.za/thesis/available/etd-04292013-151837/unrestricted/O0front.pdf Accessed: 15 Apr. 2014

Ehrenberg, A., Barnard, N., Kennedy, R., \& Bloom, H. (2002). Brand advertising as creative publicity. Journal of Advertising Research, 42(4): 7-18

Eun, H.Y., \& Kim, H.S. (2009). An affectability consumer's attitudes toward advertising-based interactive installation in public transportation, Paper presented at the International Association Society of Design Research Conference, 18 - 22 Oct 2009, Seoul, Korea. pp99 - 112.

Gray, J. (2008). How to move into moving media. Journal of Marketing, 11(5):40-41. Available from: http://www.sabinet.co.zalabstracts /mfsa1/mfsa1_apr_2008_a24.html Accessed: 30 May. 2014.

Jordaan, Y., \& Ehlers, L. (2009). Young adult consumers' media usage and online purchase likelihood. Journal of Family Ecology and Consumer Sciences, 37(1): 24-34.

Jordaan, Y., Ehlers, L., \& Grove, J. M. (2011). Advertising credibility across media channels: perceptions of Generation Y consumers. Communicare: Journal for Communication Sciences in Southern Africa, 30(1): 1-20.

Jurca, M.A. (2010). The forms of unconventional advertising - a theoretical approach. Management and Marketing from Craiova, (2): 323-333. [Online] Available from: http://www.mnmk.ro/documents/2010ed2/15_Alina\%20Jurca\%20FFF.pdf [Accessed: 2010-0405].

Lopez-Pumarejo, T.A., \& Myles, B. (2009). The renaissance of outdoor advertising: from Harlem to Hong Kong, American Journal of Business, 24(2): 33-40.

Magna Global. (2011). Advertising forecast. Magna Global. http://www.neoadvertising.com/ch/wp-content/uploads/2011/06/2011MAGNAGLOBAL-Advertising-Forecast-Abbreviated.pdf Accessed: 5 Mar. 2012.

Moriarty, S.E., Mitchell, N., \& Wells, W. 2012. Advertising \& IMC: Principles and Practice. Upper Saddle River, NJ: Pearson. 
Nagel, P., \& Louw, S. (2004). Mass media advertisements: responses to selected advertisements in semi-urban Limpopo. Communicatio, 30(2): 98-113.

Nielson Media Research. (2012). Nielson Adspend Investment in South Africa.

O'Guinn, T.C., Allen, C.T., \& Semenik, R.J. (2012). Advertising. $2^{\text {nd }}$ ed. Cincinnati, OH: South-Western College.

OHMSA. (2012). OOH classification matrix. Out-of-home Media Association of South Africa. http://www.ohmsa.co.za/Out_of_Home Classification_Matrix.pdf Accessed: 6 Feb. 2012.

Osborne, A.C., \& Coleman, R. (2008). Out door advertising recall: A comparison of newer technology and traditional billboards. Journal of Current Issues and Research in Advertising, 30 (1): 13-30.

Pauwels, L. (2005). Posters, billboards and grassroots media relating to TB and AIDS in the Free State and Lesotho. Acta Academica, 1:337-353.

Prendergast, G., \& Hang, C. (1999). The effectiveness of exterior bus advertising in Hong Kong. Journal of International Consumer Marketing, 11(3): 33-50.

Roux, T., Van Der Waldt, D.L.R., \& Ehlers, L. (2013). A classification framework for out-of-home advertising media in South Africa, Communicatio: South African Journal for Communication Theory and Research, 39(3): 383-401.

Shimp, T.A. (20100. Advertising promotion and other aspects of integrated marketing communications. $7^{\text {th }}$ ed. Mason, $\mathrm{OH}$ : South Western Cengage Learning.

Sissors, J.Z. \& Baron, R.B. (2010). Advertising media planning. $7^{\text {th }}$ ed. New York, NY: McGraw Hill.

Smith, R. E., \& Yang, X. 2004. Toward a general theory of creativity in advertising: Examining the role of divergence. Marketing Theory, 4(1-2): 31-58.

Taylor, C.R. \& Franke, G.R. (2003). Business perceptions of the role of billboards in the U.S. Economy. Journal of Advertising Research, 43(2): 150-161.

Taylor, C.R., Franke, G.R., \& Bang, H. (2006). Use and effectiveness of billboards: Perspectives from selective-perception theory and retail-gravity models. Journal of Advertising, 35(4): 21-34.

Turley, L.W., \& Shannon, J.R. 2000. The impact and effectiveness of advertisements in a sports arena. Journal of Services Marketing, 14(4): 323-336.

Twenge, J.M. (2010). A review of the empirical evidence on generational differences in work attitudes, Journal of Business and Psychology, 25(2): 201-210.

Twenge, J.M., \& Campbell, W. K. (2008). Generational differences in psychological traits and their impact on the workplace. Journal of Managerial Psychology, 23: 862-877.

Wilson, R.T., \& Till, B.D. (2011). Effects of outdoor advertising: does location matter? Psychology \& Marketing, 28(9):909-933.

Woodside, A. (1990). Outdoor advertising as experiments. Journal of the Academy of Marketing Science, 18(3):229-37. 